\title{
Pengaruh Keberadaan Corpus Luteum Terhadap Kualitas Oosit dan Tingkat Maturasi Oosit Kerbau Secara In Vitro
}

\section{Effect of the presence of corpus luteum on Oocyte Quality and In Vitro Maturation Rate of Buffalo Oocytes}

\author{
R. T. Raharjo ${ }^{1 *}$, Z. Udin ${ }^{2}$, dan Hendri ${ }^{2}$ \\ ${ }^{1}$ Program Pascasarjana, Fakultas Peternakan, Universitas Andalas, Padang - Indonesia \\ ${ }^{2}$ Program Studi Peternakan, Fakultas Peternakan, Universitas Andalas, Padang - Indonesia \\ *Corresponding E-mail: triraharjo24@gmail.com \\ (Diterima: 14 Agustus 2020; Disetujui: 30 September 2020)
}

\begin{abstract}
ABSTRAK
Penelitian ini bertujuan untuk mengetahui pengaruh keberadaan corpus luteum (CL) pada ovarium kerbau terhadap kualitas oosit dan tingkat maturasi oosit secara in vitro. Sebanyak 30 ovarium yang berasal dari RPH kemudian dikelompokkan berdasarkan keberadaan CL. Setelah itu oosit dikoleksi secara slicing, oosit yang diperoleh dikelompokkan berdasarkan kekompakan sel kumulus dan status sitoplasma. Maturasi pada medium Tissue Culture Medium-199 (TCM-199) yang ditambahkan Penstrep, Pregnant Mare Serum Gonadotrophin (PMSG), Hormone Chorionic Gonadotrophin (hCG) dan 3\% BSA. Maturasi in vitro dilakukan pada suhu $38,5^{\circ} \mathrm{C}$ selama 24 jam di dalam inkubator dengan konsentrasi $\mathrm{CO}_{2} 5 \%$. Evaluasi tingkat kematangan inti diklasifikasikan menjadi germinal vesicle $(\mathrm{GV})$, germinal vesicle break down (GVBD), metafase I (MI), Anafase/telophase (A/T) dan metafase II (MII). Hasil penelitian menujukkan status reproduksi tidak signifikan $(\mathrm{P}>0,05)$ mempengaruhi kualias oosit kerbau. Persentase oosit berkualitas baik (Grade A dan B) pada masing - masing kelompok adalah 53,76\% dan 50,19\%. Selanjutnya hasil analisis statistik menunjukkan tidak terdapat perbedaan nyata $(\mathrm{P}>0,05)$ pada tingkat maturasi di antara kedua kelompok ovarium. Persentase oosit yang mencapai tahap MII adalah sebesar $61,22 \%$ dan $62,62 \%$ pada masing - masing kelompok. Dari penelitian ini dapat disimpulkan kualitas oosit dan tingkat maturasi oosit yang mampu mencapai tahap MII tidak signifikan dipengaruhi oleh status reproduksi ovarium.
\end{abstract}

Kata kunci: kualitas oosit, tingkat maturasi, corpus luteum, ovarium kerbau

\section{ABSTRACT}

This research aims to determine corpus luteum (CL) on the buffalo ovaries on oocyte quality and in vitro maturation of oocytes. A total of 30 ovaries from the slaughterhouse were grouped based on the presence of CL. Oocytes were collected by slicing techniques, then grouped based on the cumulus cell layer and cytoplasmic status. The maturation medium was Tissue Culture Medium-199 (TCM-199) was added by Penstrep, Pregnant Mare Serum Gonadotrophin (PMSG), Hormone Chorionic Gonadotrophin $(h C G)$, and 3\% BSA. The maturation of in vitro is conducted at 38, 5oC for 24 hours in an incubator with $5 \%$ CO2 concentration. Evaluation of maturation was classified into germinal vesicles (GV), germinal vesicles break down (GVBD), metaphase I (MI), Anafaseltelophase (A/T), and metaphase II (MII). The percentage of good quality oocytes (Grade A and B) in each group were 53,76\% and 50,19\%. Furthermore, the statistical analysis results showed no significantly different $(P>0.05)$ at the maturation rate between the two ovarian groups. The percentage of oocytes reaching the MII stage was $61,22 \%$ and $62,62 \%$ in each group. The percentage of oocytes reaching the MII stage was $59.75 \%$ and $58.33 \%$ in each group. Conclusion of this study, the quality of oocytes and the maturation rate of oocytes that reaches the MII stage are not significantly affected by the reproductive status of the ovaries.

Keywords: oocyte quality, maturation rate, corpus luteum, buffalo ovaries 


\section{PENDAHULUAN}

Penerapan teknologi reproduksi adalah salah satu upaya yang dapat dilakukan dalam meningkatkan produktifitas ternak. Kemajuan teknologi reproduksi pada ternak memungkinkan masalah penurunan populasi yang terjadi pada ternak juga dapat diatasi. Salah satu upaya yang dilakukan dalam mengatasi masalah tersebut adalah pemanfaatan program inovasi teknologi reproduksi dengan memperpendek selang beranak, melalui manipulasi berahi dan superovulasi (Widyastuti dan Rasad, 2015). Selain itu teknologi reproduksi yang dapat diaplikasikan untuk meningkatkan populasi ternak kerbau adalah dengan produksi embrio secara in vitro (PEIV).

Secara teoritis teknik PEIV dapat dilakukan dengan memanfaatkan oosit yang berasal dari ovarium ternak betina yang masih hidup ataupun dari ovarium ternak betina yang telah di potong. Keunggulan teknik PEIV salah satunya adalah dalam upaya penyelamatan materi genetik dari ternak yang mengalami gangguan pada fungsi reproduksi, ternak yang mengalami kematian atau mengalami penyakit dan gangguan pada fungsi tubuh. Teknik ini memungkinkan pelaksanaan proses maturasi oosit, fertilisasi oosit dengan spermatozoa serta perkembangan embrio dapat dilakukan pada lingkungan buatan di luar tubuh dalam suatu sistem biakan sel (Syaiful et al., 2011). Karena oosit adalah tujuan utama dari pemanfaatan ovarium dari RPH oleh karena itu kualitas serta kompetensi oosit perlu untuk diperhatikan karena hal ini merupakan parameter penting dalam proses maturasi in vitro serta akan menentukan tingkat keberhasilan perkembangan embrio.

Terdapat berbagai faktor yang mempengaruhi kualitas dan jumlah oosit diantaranya umur, metode koleksi dan status reproduksi (Udin et al., 2020). Pada hakikatnya oosit yang terdapat pada lingkungan folikel yang berada pada ovarium pertumbuhannya mengikuti siklus tertentu (Parera dan Lenda, 2019). Keberadaan CL Keberadaan CL pada ovarium dapat mengindikasikan jenis hormon yang berperan dalam pertumbuhan dan perkembangan oosit (Widyastuti et al., 2018). Pada fase luteal keberadaan CL berkorelasi positif terhadap jumlah folikel, hal ini dikarenakan hormon progesteron yang dihasilkan oleh CL berperan terhadap hambatan pertumbuhan dan perkembangan folikel menjadi folikel dominan, hambatan terhadap folikel dominan akan menghilangkan pengaruh inhibin (Kor, 2014), sehingga pertumbuhan folikel subordinat dapat terjadi meskipun terdapat CL pada ovarium (Boediono et al., 2006). Selain itu PenitenteFilho et al. (2015) menambahkan bahwa adanya hormon progesteron memungkinkan pertumbuhan folikel menghasilkan oosit dengan kualitas yang baik dan selanjutnya akan berpengaruh terhadap perkembangan oosit dan embrio yang dihasilkan. Penelitian ini dilakukan untuk mengetahui pengaruh keberadaan corpus luteum pada ovarium dalam menghasilkan oosit berkualitas baik dan tingkat maturasi oosit kerbau secara in vitro .

\section{METODE}

\section{Koleksi Oosit}

Ovarium kerbau yang digunakan berasal dari rumah potong hewan (RPH) dibersihkan dan dipisahkan bagian lemak dan jaringan pada ovarium, selanjutnya dicuci dengan $\mathrm{NaCl}$ fisiologis. Media yang digunakan selama transportasi menuju laboratorium adalah $\mathrm{NaCl}$ fisiologis $0,9 \%$ yang ditambahkan dengan antibiotik penisilin-streptomisin dan disimpan dalam termos dengan temperatur konstan $37^{\circ} \mathrm{C}$. Setelah sampai di laboratorium ovarium kembali di cuci dengan $\mathrm{NaCl}$ fisiologis sebanyak 3 kali kemudian ovarium dikelompokkan berdasarkan keberadaan corpus luteum, $\mathrm{CL}+$ untuk kelompok adanya nya CL dan CL- untuk kelompok tidak adanya CL. Koleksi oosit dilakukan secara slicing dengan menggunakan media berupa PBS (Phospate Buffer Saline) yang ditambahkan dengan Penstrep dan 3\% BSA (Bovine 
Tabel 1. Persentase kualitas oosit

\begin{tabular}{ccccccc}
\hline \multirow{2}{*}{ Perlakuan } & Jumlah & Jumlah & \multicolumn{4}{c}{ Grade oosit (\%) } \\
\cline { 4 - 7 } & ovarium & oosit & A & B & C & D \\
\hline CL+ & 45 & 478 & $15(3,14)$ & $242(50,62)$ & $103(21,55)$ & $118(24,68)$ \\
CL- & 45 & 512 & $28(5,47)$ & $229(44,72)$ & $119(23,24)$ & $136(26,56)$ \\
\hline
\end{tabular}

Keterangan: $\mathrm{CL}+=$ corpus luteum; $\mathrm{CL}-=$ tanpa corpus luteum

Serum Albumin). Oosit yang diperoleh dikelompokkan berdasar kekompakan sel kumulus dan status sitoplasma. Grade A adalah oosit memiliki sitoplasma yang seragam dan memiliki lebih dari lima lapisan sel kumulus yang kompak. Grade B adalah oosit memiliki sitoplasma yang seragam dan terdapat tiga sampai lima lapisan sel kumulus yang kompak. Grade $\mathrm{C}$ adalah oosit memiliki satu lapisan sel kumulus yang tidak lengkap dan sedikit ooplasma yang homogen dan Grade D adalah oosit tidak memiliki sel kumulus atau tidak memiliki ooplasma yang homogen (Kakkassery et al., 2010).

\section{Maturasi Oosit}

Oosit hasil koleksi dicuci pada media maturasi sebanyak tiga kali dan selanjutnya dimaturasi pada media Tissue Culture Medium-199 (TCM-199) yang ditambahkan Penstrep, Pregnant Mare Serum Gonadotrophin (PMSG), Hormone Chorionic Gonadotrophin (hCG) dan 3\% BSA. Oosit dimaturasi pada drop - drop media maturasi sebanyak $100 \mu$ L untuk $10-15$ oosit, kemudian ditutup dengan mineral oil. Maturasi in vitro dilakukan pada suhu $38,5^{\circ} \mathrm{C}$ selama 24 jam di dalam inkubator dengan konsentrasi $\mathrm{CO}_{2} 5 \%$.

\section{Evaluasi Kematangan Oosit}

Oosit yang telah dimaturasi kemudian didenudasi sel - sel kumulusnya dengan cara dipipet berulang - ulang dalam medium PBS dan 2\% BSA (Udin et al., 2020), setelah itu dibuat preparat dan difiksasi dalam larutan ethanol absolute dan asam asetat (3:1) selama 48 jam (Nanda, 2017). Setelah itu preparat diwarnai dengan $2 \%$ aceto orcein selama lima menit dan status inti oosit diamati di bawah mikroskop dengan pembesaran 40x10. Evaluasi tingkat kematangan inti diklasifikasikan menjadi germinal vesicle $(\mathrm{GV})$, germinal vesicle break down (GVBD), metafase I (MI), Anafase/telophase (A/T) dan metafase II (MII).

\section{Analisis Statistik}

Data kualitas oosit dan tingkat maturasi oosit kerbau secara in vitro dianalisis dengan menggunakan uji proporsi (Sudjana, 2005).

\section{HASIL DAN PEMBAHASAN}

\section{Pengaruh Status Reproduksi Terhadap Kualitas Oosit}

Salah satu faktor utama yang menjadi indikator tingkat keberhasilan perkembangan embrio adalah kualitas oosit. Oosit yang digunakan dalam proses produksi embrio secara in vitro adalah oosit berkualitas baik yaitu oosit grade A dan B yang ditandai dengan jumlah lapisan sel kumulus yang mengelilingi oosit dan sitoplasma yang homogen. (Manjunatha et al., 2007). Hasil analisis statistik menunjukkan bahwa keberadaan CL pada ovarium tidak signifikan $(\mathrm{P}>0,05)$ mempengaruhi kualitas oosit yang dihasilkan pada masing - masing grade oosit (Tabel 1). Persentase oosit yang berkualitas baik (A dan B) paling tinggi berasal dari ovarium dengan corpus luteum sebesar 53,76\%. Berbeda dengan hasil penelitian yang sebelumnya dimana menurut Penitente-Filho et al. (2015) menyatakan bahwa kehadiran CL memiliki pengaruh yang lebih besar pada kemungkinan untuk memperoleh oosit dengan kualitas baik.

Menurut Jaswandi et al. (2016) perbedaaan jumlah oosit yang diperoleh dari ovarium yang memiliki status reproduksi berbeda disebabkan oleh perbedaan tingkat perkembangan folikel pada ovarium. 
JPI Vol. 22 (3): 353-359

Tabel 2. Persentase tingkat maturasi

\begin{tabular}{lccccccc}
\hline \multirow{2}{*}{ Perlakuan } & Jumlah & jumlah & \multicolumn{5}{c}{ Tingkat Maturasi (\%) } \\
\cline { 5 - 8 } & ovarium & oosit & GV & GVBD & MI & A/T & MII \\
\hline CL+ & 45 & 196 & $56(28,57) a$ & $20(10,20) a$ & $0 \mathrm{a}$ & 0 & $120(61,22) \mathrm{a}$ \\
CL- & 45 & 198 & $54(27,27) \mathrm{a}$ & $16(8,08) \mathrm{a}$ & $4(2,02) \mathrm{b}$ & 0 & $124(62,62) \mathrm{a}$ \\
\hline
\end{tabular}

Keterangan: $\mathrm{CL}+=$ corpus luteum; $\mathrm{CL}-=$ tanpa corpus luteum

Pertumbuhan folikel dan oosit selama siklus estrus dipengaruhi oleh beberapa jenis hormon diantaranya progesteron, estrogen dan inhibin (Boediono et al., 2006). Gelombang pertumbuhan folikel di dalam ovarium diawali dari perekrutan, seleksi dan atresi. Pada hewan monokotus, dalam satu siklus estrus hanya menghasilkan satu folikel yang akan terpilih menjadi folikel dominan dan selanjutnya mengalami ovulasi ketika terjadi luteolisis (Gustina et al., 2017). Perkembangan folikel menjadi folikel dominan akan memberikan pengaruh negatif terhadap kompetensi perkembangan oosit hal ini dikarenakan dihasilkannya estrogen dan inhibin sehingga memberikan umpan balik negatif terhadap sekresi FSH. Menurut Ginther et al. (1996) penurunan konsentrasi FSH akan menyebabkan folikel - folikel subordinat mengalami hambatan perkembangan dan selanjutnya akan mengalami atresi.

Hasil yang tidak berbeda nyata pada perlakuan diakibatkan karena kehadiran CL pada fase luteal menghasilkan hormon progesteron, dimana hormon ini mengakibatkan terhambatnya pertumbuhan folikel dominan untuk mencapai ovulasi karena adanya umpan balik negatif terhadap pelepasan hormon estrogen dan inhibin. Pelepasan hormon FSH tidak dipengaruhi oleh adanya hormon progesteron, akan tetapi hambatan terhadap FSH dipengaruhi oleh adanya inhibin yang dihasilkan selama siklus estrus (Boediono et al., 2006). Hambatan sekresi estrogen dan inhibin oleh progesteron akan menekan pengaruh negatif folikel dominan terhadap pertumbuhan dan perkembangan folikel subordinat lainnya (Parera dan Lenda, 2019). Selain itu hormon progesteron memungkinkan folikel terekspos untuk periode yang lebih lama sebagai akibat dari rendahnya level LH dan hal ini memungkinkan untuk memperoleh oosit yang berkualitas baik (Penitente-Filho et al., 2015). Sebaliknya pada ovarium tanpa CL, tidak adanya kehadiran CL tidak menyebabkan efek negatif progesteron pada hipofisis anterior sehingga kadar estrogen dan progesteron tetap seimbang yang memungkinkan pertumbuhan folikel (Khandoker et al., 2016). Pada ovarium tanpa CL, penurunan kadar progesteron mengakibatkan tidak adanya kontrol umpan balik negatif terhadap hipotalamus dan hipofisa anterior, hal ini akan menyebabkan gonadotropin disekresikan oleh hipotalamus dan FSH serta LH akan disekresikan oleh hipofisa anterior (Parera dan Lenda, 2019), kemudian kehadiran hormon ini akan menyebabkan pertumbuhan folikel ovarium lebih cepat.

\section{Pengaruh Status Reproduksi Terhadap Tingkat Maturasi}

Hasil analisis statistik menunjukkan bahwa keberadaan CL pada ovarium tidak memberi pengaruh signifikan terhadap tingkat maturasi oosit kerbau secara in vitro. Persentase tingkat maturasi oosit yang mencapai tahap metafase II (MII) yang paling tinggi adalah pada kelompok CL- yakni sebesar 62,62\% (Tabel 2). Hasil penelitian ini sesuai dengan pendapat Mahesh et al. (2014) yang menyatakan bahwa tidak terdapat perbedaan yang signifikan terhadap tingkat maturasi oosit kerbau secara in vitro dari ovarium dengan atau tanpa CL. Singh et al. (2001) menambahkan adanya CL pada ovarium ternak bunting tidak mempengaruhi kompetensi meiosis oosit. Lebih lanjut Shabankareh et al. (2015) melaporkan bahwa kompetensi perkembangan oosit 
diakibatkan oleh adanya heterogenitas dalam perkembangan folikel, ketika diameter folikel meningkat dan diameter oosit meningkat maka diperoleh kompetensi perkembangan oosit yang baik dan mayoritas oosit mampu mendukung pembuahan dan perkembangan embrio. Namun pendapat berbeda dilaporkan oleh Widyastuti et al. (2018) bahwa tingkat maturasi oosit yang berasal dari ovarium dengan status reproduksi $\mathrm{CL}+$ lebih tinggi dibanding kelompok CL-. Kemudian juga Zilaitis et al. (2018) menyatakan bahwa CL yang terdapat pada ovarium akan meningkatkan jumlah oosit yang mencapai tingkat kematangan setelah proses maturasi oosit secara in vitro. Hal ini dikarenakan pada fase luteal, corpus luteum menghasilkan hormon progesteron. Hormon ini bersama dengan androgen berperan dalam menghambat terjadinya atresia oosit. Selanjutnya dijelaskan bahwa kombinasi dari kedua hormon ini berperan meningkatkan jumlah oosit yang menglami pematangan inti (Borman et al., 2004).

Selain kehadiran CL, kualitas oosit adalah salah satu parameter yang mempengaruhi tingkat maturasi oosit secara in vitro. Menurut Singh et al. (2001) kualitas oosit menunjukkan perbedaan yang signifikan terhadap tingkat maturasi oosit oosit secara in vitro. Kualitas oosit ditentukan berdasarkan jumlah lapis sel kumulus. Menurut Palmerini et al. (2014) menjelaskan bahwa secara morfologis, kualitas oosit ditentukan oleh bentuk ultrastrukturalnya. Oosit yang digunakan untuk proses maturasi secara in vitro adalah oosit berkualitas baik dengan lapisan sel kumulus yang kompak serta memiliki sitoplasma yang homogen. Pada proses fertilisasi secara in vitro, adanya sel kumulus menjadi salah satu faktor yang dapat mempengaruhi tingkat pematangan oosit. Menurut alvarez et al. (2009) secara metabolis, sel kumulus menghasilkan metabolit yang mendukung pematangan sitoplasma dan inti melalui gap junctions yang menjadi pintu masuk metabolit ke dalam ooplasma. Selain itu sel kumulus berperan dalam menginduksi pembelahan meiosis dan membantu pematangan sitoplasma.

\section{KESIMPULAN}

Berdasarkan hasil penelitian ini dapat disimpulkan bahwa keberadaan corpus luteum pada ovarium tidak signifikan mempengaruhi kualitas oosit yang dihasilkan serta tingkat maturasi oosit kerbau secara in vitro.

\section{DAFTAR PUSTAKA}

Alvarez, G. M., G. C. Dalvit., M. V. Achi., M. S. Miguez, and P. D. Cetica. 2009. Immature Oocyte Quality and Maturational Competence of Porcine Cumulus-Oocyte Complexes Subpopulations. Biocell 33(3): 167177.

Boediono, A., Yulnawati, dan M. A. Setiadi. 2006. Tingkat pematangan inti oosit domba dari ovarium dengan status reproduksi dan medium maturasi yang berbeda. Science Direct. 13(4): 131136.

Borman, S. M., C. L. Chaffin., K. M. Schwinof., R. L. Stouffer, and M. B. Zelinski-Wooten. 2004. Progesterone promotes oocyte maturation, but not ovulation, in nonhuman primate follicles without a gonadotropin surge. Biol. Reprod. 71(1): 366-373.

Ginther, O. J., M. C. Wiltbank., P. M. Fricke., J. R. Gibbons, and K. Kot. 1996. Selection of the dominant follicle in cattle. Biol. Reprod. 55: 1187-1194.

Gustina, S., H. Hasbi., N. W. K. Kurnia., M. A. Setiadi, dan I. Supriatna. 2017. Kualitas oosit kerbau dari status reproduksi ovarium yang berlainan. Jurnal Sain Veteriner. 35(2): 216-222.

Mahesh, Y. U., M. M. Rao., P. Sudhakar, and K. R. S. Sambasiva. 2014. Effect of harvesting technique and presence or absence of corpus luteum on in vitro 
development after parthenogenetic activation of oocytes recovered from buffalo ovaries. Veterinary World, 7: 315-320.

Jaswandi., M. A. Setiadi., A. Boediono,, M. R. Toelihere, dan Y. Sukra. 2016. Potensi ovarium yang dipotong untuk produksi embrio in vitro. Med. Pet. 24(2): 30-33.

Kakkassery, M. P., V. Vijayakumaran, and T. Sreekumaran. 2010. Effect of cumulus oocyte complex morphology on in vitro maturation of bovine oocytes. J. Vet Anim Sci. 41: 12-17.

Khandoker, M. A. M. Y., K., N. F. Atiqah, and N. Ariani. 2016. Effect of ovarian types and collection techniques on the number of follicles and the quality of cumulus-oocytes-complexes. Bangladesh Journal Animal Science 45(3): 10-16.

Kor, N. M. 2014. The effect of corpus luteum on hormonal composition of follicular fluid from different sized follicles and their relationship to serum concentrations in dairy cows. Asian Pacific Journal of Tropical Medicine 7: S282-S288.

Manjunatha, B. M., P. S. P. Gupta., J. P. Ravindra., M. Devaraj., H. S. Ramesh, and S. Nandi. 2007. In vitro developmentals competence of buffalo oocytes collected at various stages of the estrous cycle. Theriogenology 68 : 882-888.

Nanda, S. 2017. Tingkat maturasi oosit dan perkembangan awal embrio sapi dengan penambahan insulin pada media maturasi dan atau media kultur secara in vitro. Tesis. Sekolah Pascasarjana Institut Pertanian Bogor. Bogor.

Palmerini, M. G., S. A. Nottola., G. G. Leoni., S. Succu., X. Borshi., F. Berlinguer., S. Naitana., Y. Bekmukhambetov, and G. Macchiarelli. 2014. In vitro maturation is slowed in prepubertal lamb oocytes: ultrastructural evidences. Reprod. Biol. Endocrinol. 24(12): 115.
Parera, H. dan V. Lenda. 2019. Pengaruh corpus luteum dan folikel dominan terhadap kualitas morfologi oosit sapi bali-timor. Jurnal Kajian Veteriner 3(1): 63-70.

Penitente-Filho, J. M., C. R. Jimenez., A. M. Zolini., E. Carrascal., J. L. Azevedo., C. O. Silveira., F. A. Oliveira, and C. A. A. Torres. 2015. Influence of Corpus Luteum and Ovarian Volume on The Number and Quality of Bovine Oocytes. Animal Science Journal. 86: 148-152.

Penitente-Filho, J. M., E. Carrascal., F. A. Oliveira1., A. M. Zolini., C. T. Oliveira., Í. A. C. Soares, and C. A. A. Torres. 2014. Influence of Dominant Follicle and Corpus luteum on Recovery of Good Quality Oocytes for in vitro Embryo Production in Cattle. British Biotechnology Journal. 4(12): 13051312.

Shabankareh, H. K., M. H. Shahsavari., H. Hajarian, and G. Moghaddam. 2015. In vitro developmental competence of bovine oocytes: Effect of corpus luteum and follicle size. Iranian journal of reproductive medicine. 13(10): 615622.

Singh, S., O. P. Dhanda, and R. K. Malik. 2001. Effect of the presence of corpus luteum on oocyte recovery and subsequent maturation and fertilization in buffaloes. Asian-Aust. J. Anim. Sci. 14: 1675-1677.

Sudjana. 2005. Metoda statistika. Tarsito, Bandung.

Syaiful, F. L., R. Saladin., Jaswandi, dan Z. Udin. 2011. Pengaruh waktu fertilisasi dan sistem inkubasi yang berbeda terhadap tingkat fertilisasi sapi lokal secara in vitro. Jurnal Peternakan Indonesia. 13(1): 27-35.

Udin, Z., Masrizal., Hendri, and S. Nanda. 2020. Evaluation of different techniques in recovering of oocytes and storage duration of ovaries on the quality and 
quantity of bovine in vitro maturation. Buletin of Animal Science. 44(2): 1-7.

Widyastuti, R. dan S. D. Rasad. 2015. Tingkat kematangan inti oosit sapi setelah 24 jam preservasi ovarium. Agripet. 15(1): 72-78.

Widyastuti, R., M. R. A. A. Syamsunarno., A. Yusuf., M. R. Ridlo, dan S. Prastowo. 2018. Pengaruh keberadaan corpus luteum terhadap kualitas dan tingkat maturasi oosit domba lokal umur pubertas awal secara in vitro. Agripet. 18(2): 83-89.

Zilaitis, V., R. Juodzentyze, and G. Palubinskas. 2018. Relationship between corpus luteum and possibility dairy cows oocytes to maturation in vitro. Vet. Med. Zoot. 76(98): 119-121. 